(RESEARCH ARTICLE)

\title{
In-silico molecular docking study of some n-substituted thiazoles derivatives as FabH inhibitors
}

\author{
Shivkant Sharma *, Manish Devgun, Karan Wadhwa and Sahil Banwala \\ Institute of Pharmaceutical Sciences, Kurukshetra University, Kurukshetra, Haryana, 136119, India.
}

Publication history: Received on 19 October 2020; revised on 27 October 2020; accepted on 02 November 2020

Article DOI: https://doi.org/10.30574/wjarr.2020.8.2.0387

\begin{abstract}
Heterocyclic compounds with thiazole moiety are one of the most promising compounds in the medicinal chemistry possessing numerous therapeutic activities. The present was designed to study the high throughput in silico screening of 10 designed 2-phenyl-amino thiazole derivatives as a potent FABH inhibitor in Molegro virtual docker software (Version 6.0) using 3iL9 as PDB. The docking results showed mol dock score of -90.94 with four hydrogen bonding for the standard drugs griseofulvin, while on the other hand, N-substituted thiazole derivatives S2, S5, S6, S7, S8, and S9 exhibited excellent mol dock score, ranged from -102.612 to -144.236, hydrogen bonding (4-10), and docking score ranged from -104.873 to -143.593 . Similarly, another in silico study was done using online PASS software and the compounds S1, S2, S5, S6, S7, S8, and S9 have Pa ranged between 0.310 to 0.411 and showed good antibacterial activity whereas, compounds having Pa ranged between 0.216 to 0.334 demonstrated potent antifungal activity when compared to standard drugs. Thus, the present study affirmed the significant antimicrobial potential of some designed $\mathrm{N}$ substituted thiazole derivatives based on their mol dock values and other parameters when studies in silico and the obtained results will provide data support and offer perspectives in future researches to develop potent antimicrobial agents from these $\mathrm{N}$-substituted thiazole derivatives.
\end{abstract}

Keywords: Antimicrobial; Antifungal; Thiazole; Molecular Docking; FabH Inhibitors

\section{Introduction}

Thiazole, a five-member ring has molecular formula $\mathrm{C}_{3} \mathrm{H}_{3} \mathrm{NS}$, indicating the presence of sulfur and nitrogen atoms, this ring plays a very crucial and important role amongst heterocyclic compounds [1]. Thiazoles can be synthesized in the laboratory by using the well-known Hantzsch process and also founds in natural sources likes vitamin B1 or marine sources [2,3]. Thiazoles containing compounds have different biological activities like antibacterial [4], anticancer [5], antimalarial [6], antifungal [7], anti-inflammatory [8], antiepileptic [9], anti-oxidants [10].

\subsection{Docking studies}

Molecular docking is defined as a technique for checking drug molecule bio-molecular interactions for the discovery of new drugs as well as a new use of the standard drug. This technique also provides us with a mechanistic study point of view and helps molecule (ligand) to bind with the specific receptor of the target at a specific region of the DNA/protein (receptor) [11]. The docking technique gives information about free energy, the stability of complex along with the binding energy of a definite compound. Molecular docking is very useful to forecast the outcome of the ligand-receptor complex [12]. Molecular docking is used to evaluate the exact confirmation of the ligand-receptor complex with an objective of least binding energy. The docking software forecasted the various parameters of binding free energy in terms of the hydrogen bond, electrostatic, torsional free energy, dispersion, and repulsion, desolvation total internal energy, and unbound system's energy [13]. Discovery studio software helps in preparing ligand in PDB format, and by

\footnotetext{
* Corresponding author: Shivkant Sharma

PG Research ScholarInstitute Of Pharmaceutical Sciences, Kurukshetra University,Kurukshetra, Haryana, 136119.
} 
using a database it consequently helps to find distinct targets. These mechanisms can create ligands group based on their interaction with target proteins. In this method, there is a pre-defined sample to evaluate the possible confirmation with complex. This depends on the doc score [14]. The IR, NMR spectroscopy as well as X-ray crystallography are the techniques for the demonstration and confirmation of the 3D structure of molecule/ bio-molecular targets. Homology modeling is an easy mode to examine the structure of an unknown protein with a known protein structure [15].

In the docking process, if the rejection of a new conformer exists then the process is continued until there is a minimum of one confirmation. The binding orientation of docked conformers is much more complicated than their binding free energies as well as their experimental binding affinities. To overcome this situation, extraordinary scoring capabilities are tagged along with their different score features equal to dock pose with a view forecast false positives which are not true [16].

Numbers of software like Molegro Virtual Docker (MVD), Auto Dock, DOCK, Flex X, Glide, and GOLD are used in docking study. Glide and Molegro Virtual Docker are the software that is used worldwide on a large scale. In the present study, we used the Molegro Virtual Docker Version 4.0.2 software for docking studies. MVD is a convenient software for forecasting protein-ligand interaction. It offers top-notch docking primarily relied on a unique optimization approach blended along with a person's focusing on usability as well as productivity. The docking accuracy can be enhanced through re-ranking scoring which is used to reveal maximum possible promising docking solutions.

\subsection{Potential role of FabH Target}

The major source of membrane fatty acid are type II fatty acid synthase enzyme in bacteria and plant $[17,18]$, monitored most comprehensively and precisely in Escherichia coli which bears a collection of person enzymes, easy to be encoded through separate genes. The type I fatty acid synthase enzyme can be confronted in beast wherein simple multifunctional polypeptide catalyzes all of the reactions within the continuation pathway, which makes the kind II gadget a high target for antibiotics [19,20,21]. Type II enzymes in P. falciparum aided in the evolution of antimalarial pills [22]. In the type II device, fatty acid continuation show in two carbon steps by way of the Claisen condensation of malonyl-ACP with acyl-ACP. Three enzymes mobilize the above-mentioned reactions, FabB, FabF, and FabH. FabH commences the system, whereas FabB and FabF carry out the continuation reactions in the forthcoming cycles of fatty acid continuation. FabH operates through a ping-pong phenomenon with the help of an acetyl-enzyme intermediate (parent 1). FabB and FabF both have huge and intersecting substrate precision and make use of various acyl-ACPs which are among four as well as sixteen carbons long. FabH performs as a crucial agent to regulate the cycle. Thiolactomycin is a natural product that inhibits FabH $[23,24,25]$.

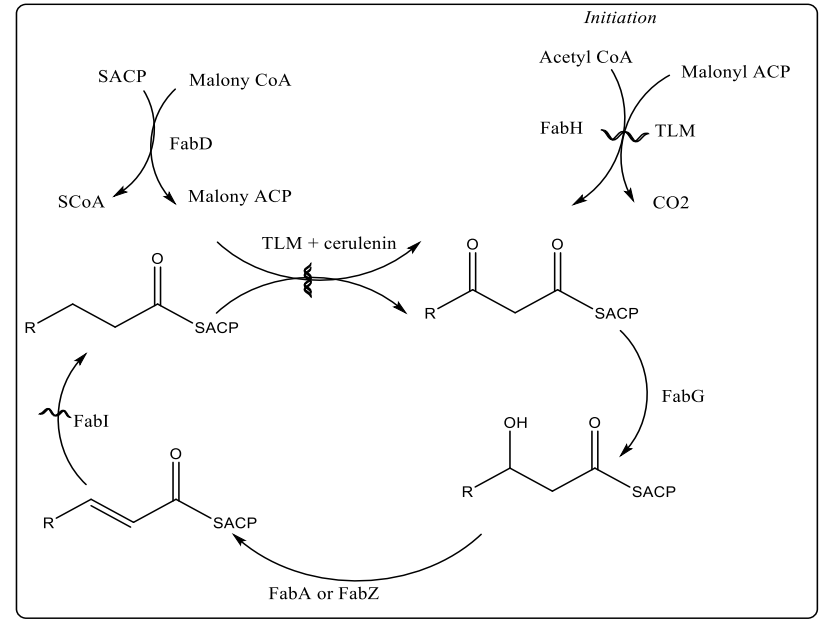

Figure 1 Mechanism of inhibiting of fatty acid synthesis by FabH inhibitor [26]

The present was designed to study the high throughput in silico screening of 10 designed 2-phenyl-amino thiazole derivatives as a potent FABH inhibitor in Molegro virtual docker software (Version 6.0) using 3iL9 as PDB. 


\section{Material and methods}

Computational approaches progressed to overcome the problem of diverse derivatives. As all the possible compounds cannot be synthesized so easily nor all the available ones can be tested, molecular modeling plays a crucial role as it is easy to understand as well as favors us with a limit to a few fixed numbers of compounds. The docking technique works out the potential structure of a substance to the site of a receptor. Docking studies have been organized with a group of 2,4- disubstituted thiazole derivatives exploited by Molegro virtual docker 6.0 on FabH inhibitor (PDB ID 3iL9) [27]. The X-ray images were utilized from the supermolecule knowledge bank (Protein Data Bank).

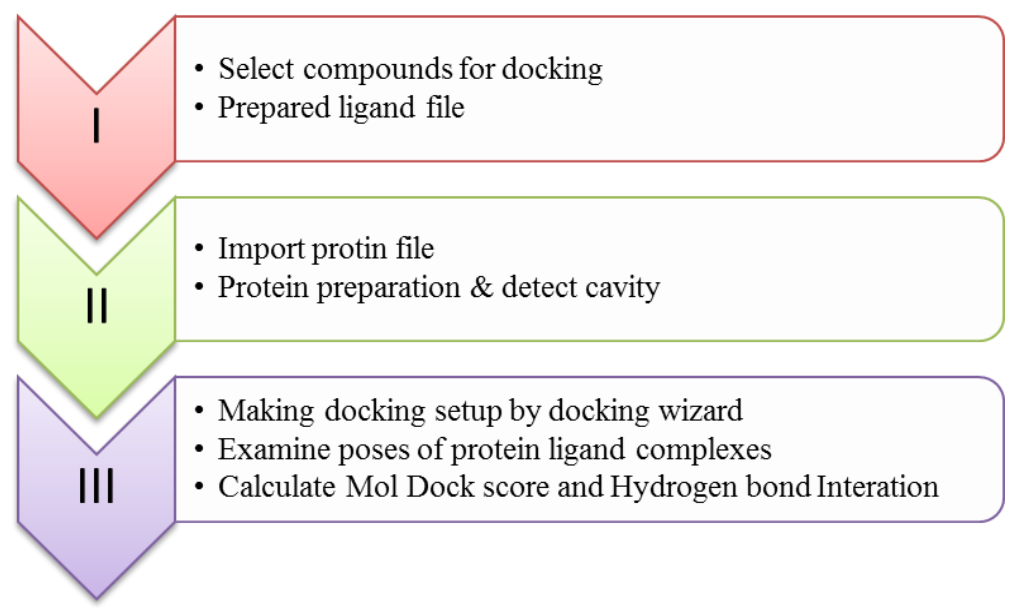

Figure 2 Steps involved in molecular docking study

\subsection{Selection of the compounds and ligand preparation}

Based on literature data, we selected 10 hypothetical compounds bearing moieties 2,4- disubstituted thiazole and docking study was performed using (PDB ID 3iL9) for anti-fungal and anti-bacterial activity using Molegro Virtual Docker. The ligand molecules were devised with the help of Marvin Sketch and then molecules were transformed to 2D and later converted to 3D applying build and optimize the method and finally cleaned in 3D. The resulted structures were stored in the MDL Molfile (*.mol) format. A single 3D image along for every successful structure was formed. The structure was imported into the workspace of docking software Molegro Virtual Docker. In this process of preparation of molecules, molecules were assigned bonds, bond order, and hybridization, charge, explicit hydrogens, and flexible torsion in ligands.

\subsection{Compound selection}

The docking studies implemented with a plethora of hypothetical compounds bearing 2,4-disubsituted thiazoles moiety are shown in Figure 3.

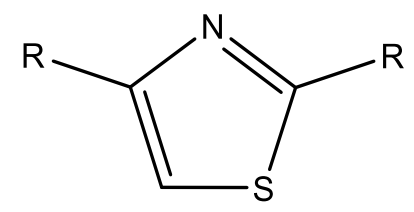

Figure 3 Basic moiety of 2,4-disubsituted thiazole

\subsection{Protein preparation and cavity detection}

In Molegro Virtual docker, the protein preparation is automatically done. Docking is a computational method for forecasting modes of action of tiny organic molecules to protein receptors. Structure formation at active site with correlations points recognized as a grid. The ligand in the binding site can be fixed at the receptor site. Several types of interaction between receptor and ligands, like van der Waal's interactions aromatic interactions are focused to estimate the binding energy. The protein receptor (PDB ID: 3iL9) was obtained from RCSB (https://www.rcsb.org/pdb protein) 


\subsection{Docking of prepared compounds}

Several poses of a ligand was formed by generating ligand docking within the active site, which demonstrates a mode of action nearby through X-ray crystallography.

Protein (PDB code: 3iL9) was downloaded from the Protein Data Bank. All designed ligands and reference ligand, griseofulvin (as standard drug) were imported in the workspace area of Molegro Virtual Docker (Ver. 4.0.2), and necessary bonds, bond orders, hybridizations, hydrogen atoms, and charges were assigned. All solvents molecules, cofactor, and co-crystallized ligands were removed from structures. The selected parameter in the studies was weight unit dock optimizer, variety of runs ten, cavity elect is user outline. Marking performa is the method which is used to select ligands from the docking wizard.

\subsection{Scoring function}

he Mol dock scoring function: Escore is described in these terms:

$E_{\text {score }}=E_{\text {inter }}+E_{\text {intra }}$

Where $\mathrm{E}_{\text {intra }}$ is the $\mathrm{E}$ inter energy of the ligand; $\mathrm{E}$ inter is the ligand-protein interaction energy

Table 1 Structures of hypothetical compounds checked for docking studies

\begin{tabular}{|l|l|l|l|l|l|}
\hline \\
Name
\end{tabular}




(2)

\section{Results and discussion}

\subsection{In silico molecular docking studies}

The interaction of standard and test compounds was compared and the score calculated as mol dock score, re-rank score, and the number of hydrogen bond interactions. The docking energy of the ligands was negative, which shows the stable binding interaction between the receptor and the ligands.

All hypothetical compounds showed good results for anti-fungal and antibacterial activity. Out of 10 compounds, compounds $\left(S_{2}, S_{6}, S_{7}, S_{8}\right.$, and $\left.S_{9}\right)$ were found to have very good results for antifungal and antibacterial activity. The docking output of 10 compounds is given in Table-2. Relevant interaction of the ligand is an important element with the presumptive binding site of the enzyme. The standard drug griseofulvin showed mol dock score -90.94 and the number of hydrogen bond interactions as 4 which is less than the hypothetical derivatives. Six derivatives $\mathrm{S}_{2}, \mathrm{~S}_{5}, \mathrm{~S}_{6}, \mathrm{~S}_{7}, \mathrm{~S}_{8}$, and $\mathrm{S}_{9}$ exhibited mol dock score (-102.612 to -144.236$)$ "i.e." higher than the standard and number of hydrogen bond interaction in-between range 4 to 10 .

The compounds which showed the highest mol dock score and hydrogen bond interaction are $\mathrm{S}_{6}, \mathrm{~S}_{7}$, $\mathrm{S}_{8}$, and $\mathrm{S}_{9}$. The $\mathrm{H}$ bond interaction with bond length $2.60 \AA ̊$ was considered a strong bond. 
Table 2 Ligand-receptor interaction data of 2,4-disubstituted thiazole using Molegro software.

\begin{tabular}{|c|c|c|c|c|c|}
\hline Sr. No & $\begin{array}{l}\text { Interaction of Amino } \\
\text { acid with bond length }\end{array}$ & $\begin{array}{l}\text { No. of } \\
\text { H-bond interaction }\end{array}$ & $\begin{array}{l}\text { Mole Doc } \\
\text { Score }\end{array}$ & $\begin{array}{l}\text { Remark } \\
\text { Score }\end{array}$ & $\begin{array}{l}\text { Docking } \\
\text { Score }\end{array}$ \\
\hline SD & 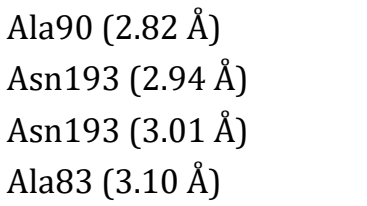 & 4 & -90.94 & -68.06 & -93.37 \\
\hline Internal ligand & $\mathrm{CSD}=112[\mathrm{~A}]$ & & & & \\
\hline $\mathrm{S}_{1}$ & $\begin{array}{l}\text { Thr81 (2.85 }) \\
\text { Ala83 (3.30 ̊̊) } \\
\text { Asn193 (2.82 ̊̊) }\end{array}$ & 3 & -125.546 & -102.50 & -126.762 \\
\hline $\mathrm{S}_{2}{ }^{*}$ & 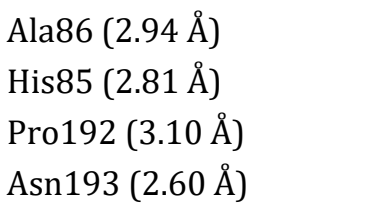 & 4 & -102.612 & -83.4416 & -104.873 \\
\hline $\mathrm{S}_{3}$ & $\begin{array}{l}\text { Asn193 (3.10 }) \\
\text { His85 (3.23 }) \\
\text { Ala83 (2.99 ̊̊) }\end{array}$ & 3 & -121.59 & -104.382 & -125.032 \\
\hline $\mathrm{S}_{4}$ & 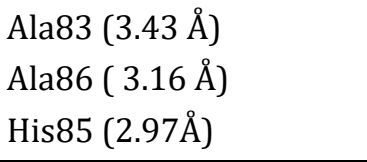 & 3 & -132.542 & -102.888 & -133.715 \\
\hline $\mathrm{S}_{5} *$ & 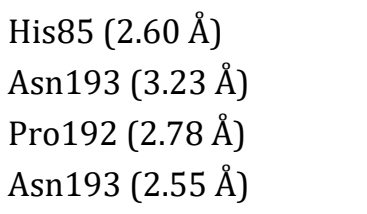 & 4 & -140.57 & -109.511 & -143.545 \\
\hline $\mathrm{S}_{6} *$ & $\begin{array}{l}\text { Asn193 (3.10 }) \\
\text { Asn193 }(2.74 \AA ̊) \\
\text { His85 }(2.85 \AA) \\
\text { Ala86 }(3.10 \AA) \\
\text { Asp107 (3.07 } \AA)\end{array}$ & 5 & -125.614 & -103.786 & -128.921 \\
\hline $\mathrm{S}_{7} *$ & $\begin{array}{l}\text { Pro192 (3.10 }) \\
\text { Asn193 (2.38 ̊̊) } \\
\text { Asn193 (2.60 ̊̊) } \\
\text { Ala83 (3.15 }) \\
\text { Asn193 (2.92 })\end{array}$ & 5 & -144.236 & -110.777 & -143.593 \\
\hline $\mathrm{S}_{8} *$ & $\begin{array}{l}\text { His85 }(2.98 \AA) \\
\text { Ala83 }(3.50 \AA) \\
\text { Asn193 (2.60 }) \\
\text { Asn193 (2.51 } \AA) \\
\text { Pro192 (2.69 })\end{array}$ & 5 & -121.939 & -86.4237 & -123.732 \\
\hline
\end{tabular}




\begin{tabular}{|c|c|c|c|c|c|}
\hline $\mathrm{S}_{9} *$ & $\begin{array}{l}\text { Thr80 }(2.60 \AA) \\
\text { Asn193 }(3.02 \AA) \\
\text { His85 }(2.60 \AA) \\
\text { Ala83 }(3.21 \AA) \\
\text { Ala83 }(3.21 \AA) \\
\text { Ala194 }(3.09 \AA) \\
\text { Arg196 }(2.60 \AA) \\
\text { Arg196 (3.04 }) \\
\text { Arg196 (3.29 }) \\
\text { Ala194 }(3.51 \AA)\end{array}$ & 10 & -123.562 & -69.4237 & -137.826 \\
\hline $\mathrm{S}_{10}$ & $\begin{array}{l}\text { Asp107 }(2.84 \AA \AA) \\
\text { Asn193 }(2.65 \AA ̊) \\
\text { Pro192 (2.60 ̊̊) }\end{array}$ & 3 & -120.44 & -93.0685 & -125.046 \\
\hline SD & $\begin{array}{l}\text { Ala90 }(2.82 \AA) \\
\text { Asn193 }(2.94 \AA) \\
\text { Asn193 }(3.01 \AA) \\
\text { Ala83 (3.10 })\end{array}$ & 4 & -90.94 & -68.06 & -93.37 \\
\hline Internal ligand & $\mathrm{CSD}=112[\mathrm{~A}]$ & & & & \\
\hline $\mathrm{S}_{1}$ & $\begin{array}{l}\text { Thr81 (2.85 ̊̊) } \\
\text { Ala83 (3.30 }) \\
\text { Asn193 (2.82 })\end{array}$ & 3 & -125.546 & -102.50 & -126.762 \\
\hline $\mathrm{S}_{2}{ }^{*}$ & $\begin{array}{l}\text { Ala86 }(2.94 \AA) \\
\text { His85 }(2.81 \AA \AA) \\
\text { Pro192 (3.10 ̊) } \\
\text { Asn193 (2.60 })\end{array}$ & 4 & -102.612 & -83.4416 & -104.873 \\
\hline $\mathrm{S}_{3}$ & $\begin{array}{l}\text { Asn193 (3.10 ̊̊) } \\
\text { His85 (3.23 }) \\
\text { Ala83 }(2.99 \AA ̊)\end{array}$ & 3 & -121.59 & -104.382 & -125.032 \\
\hline $\mathrm{S}_{4}$ & $\begin{array}{l}\text { Ala83 }(3.43 \AA) \\
\text { Ala86 ( } 3.16 \AA) \\
\text { His85 }(2.97 \AA ̊)\end{array}$ & 3 & -132.542 & -102.888 & -133.715 \\
\hline $\mathrm{S}_{5} *$ & $\begin{array}{l}\text { His85 }(2.60 \AA) \\
\text { Asn193 (3.23 } \AA) \\
\text { Pro192 (2.78 }) \\
\text { Asn193 (2.55 })\end{array}$ & 4 & -140.57 & -109.511 & -143.545 \\
\hline $\mathrm{S}_{6} *$ & $\begin{array}{l}\text { Asn193 (3.10 ̊) } \\
\text { Asn193 (2.74 }) \\
\text { His85 }(2.85 \AA) \\
\text { Ala86 }(3.10 \AA) \\
\text { Asp107 }(3.07 \AA)\end{array}$ & 5 & -125.614 & -103.786 & -128.921 \\
\hline $\mathrm{S}_{7} *$ & $\begin{array}{l}\text { Pro192 (3.10 ̊) } \\
\text { Asn193 (2.38 ̊̊) }\end{array}$ & 5 & -144.236 & -110.777 & -143.593 \\
\hline
\end{tabular}




\begin{tabular}{|c|c|c|c|c|c|}
\hline & $\begin{array}{l}\text { Asn193 }(2.60 \AA) \\
\text { Ala83 }(3.15 \AA) \\
\text { Asn193 }(2.92 \AA)\end{array}$ & & & & \\
\hline $\mathrm{S}_{8}{ }^{*}$ & $\begin{array}{l}\text { His85 }(2.98 \AA ̊) \\
\text { Ala83 }(3.50 \AA) \\
\text { Asn193 }(2.60 \AA) \\
\text { Asn193 }(2.51 \AA) \\
\text { Pro192 (2.69 })\end{array}$ & 5 & -121.939 & -86.4237 & -123.732 \\
\hline $\mathrm{S}_{9} *$ & $\begin{array}{l}\text { Thr80 (2.60 } \AA) \\
\text { Asn193 (3.02 }) \\
\text { His85 }(2.60 \AA) \\
\text { Ala83 }(3.21 \AA) \\
\text { Ala83 }(3.21 \AA) \\
\text { Ala194 (3.09 }) \\
\text { Arg196 (2.60 }) \\
\text { Arg196 (3.04 }) \\
\text { Arg196 (3.29 }) \\
\text { Ala194 }(3.51 \AA ̊)\end{array}$ & 10 & -123.562 & -69.4237 & -137.826 \\
\hline $\mathrm{S}_{10}$ & $\begin{array}{l}\text { Asp107 (2.84 }) \\
\text { Asn193 (2.65 }) \\
\text { Pro192 (2.60 })\end{array}$ & 3 & -120.44 & -93.0685 & -125.046 \\
\hline
\end{tabular}

According to these values, the title compounds display an approximate affinity to the active (3iL9) site greater than the standard (griseofulvin) compound.

A total of six compounds showed a good mole score as well as a good number of H-bond interaction as compared to the standard drug-like (griseofulvin). Compounds $\mathrm{S}_{2}, \mathrm{~S}_{5}, \mathrm{~S}_{6}, \mathrm{~S}_{7}, \mathrm{~S}_{8}$, and $\mathrm{S}_{9}$ may be considered as the best antifungal and antibacterial agents based on their docking score.

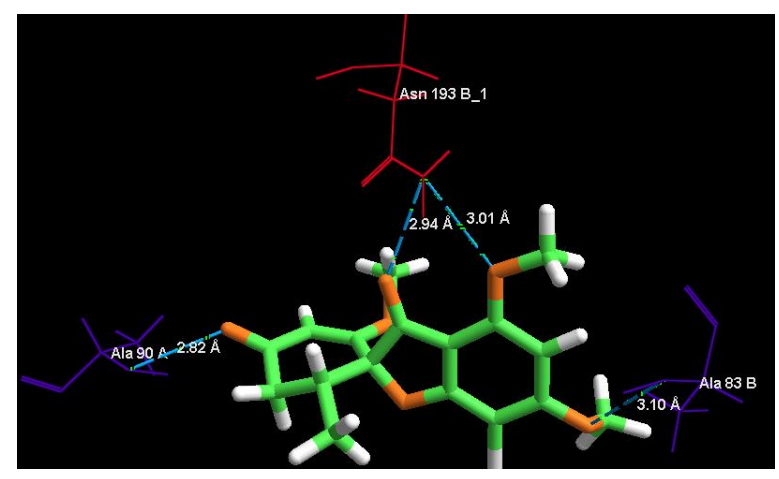

Figure 4 Standard drug Griseofulvin showed interaction with bond lengths of amino-acids Ala90 (2.82 Å), Asn193 (2.94 ̊̊), Asn193 (3.01 ̊̊) and Ala83 (3.10 Å). 


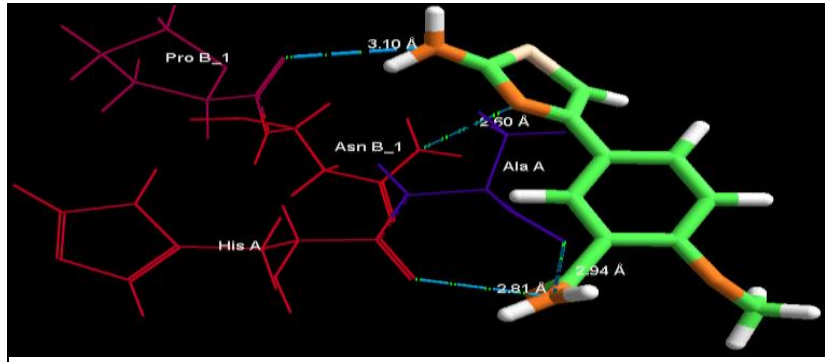

Figure 5(a) Compound $S_{2}$ showed interaction with bond lengths of amino-acids Ala86 (2.94 Å),

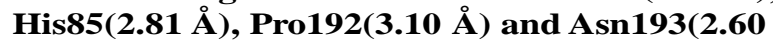
Å).

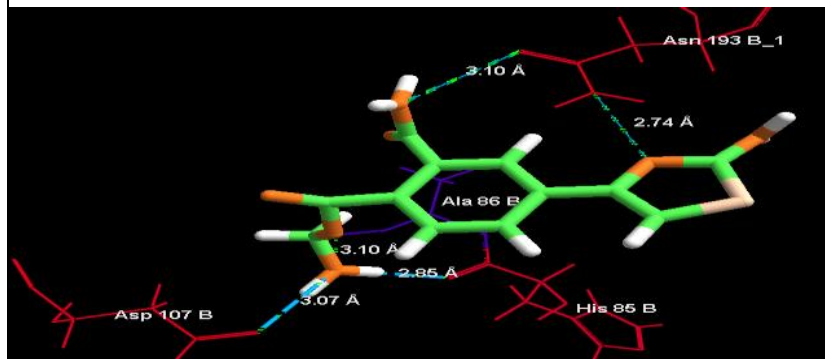

Figure 5 c) Compound $S_{6}$ showed interaction with bond lengths of amino-acids Asn193(3.10

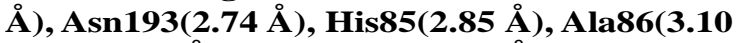
$\AA)$ and $A \operatorname{sp107}(3.07 \AA)$.

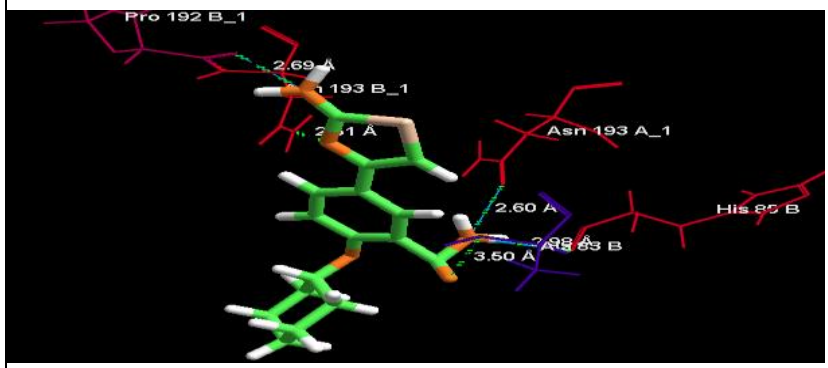

Figure 5(e)Compound $S_{8}$ showed interaction

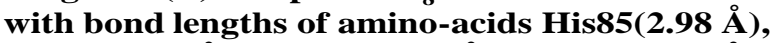

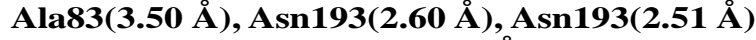
and Pro192(2.69 $\AA$ ).

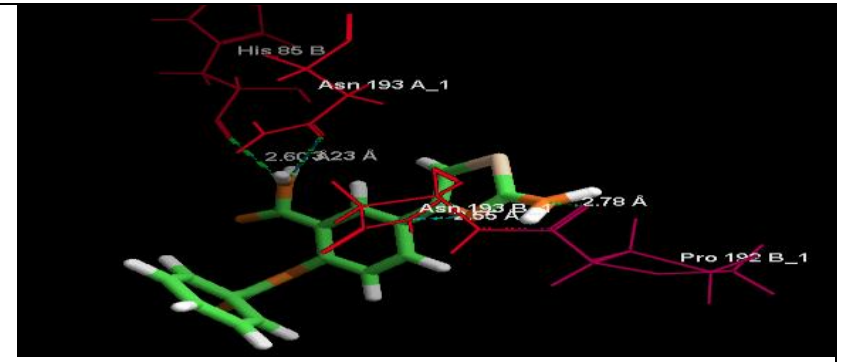

Figure 5(b) Compound $S_{5}$ showed interaction with bond lengths of amino-acids $H i s 85(2.60 \AA)$,

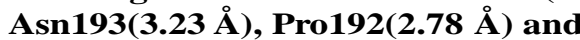
$\operatorname{Asn193(2.55\AA )}$.

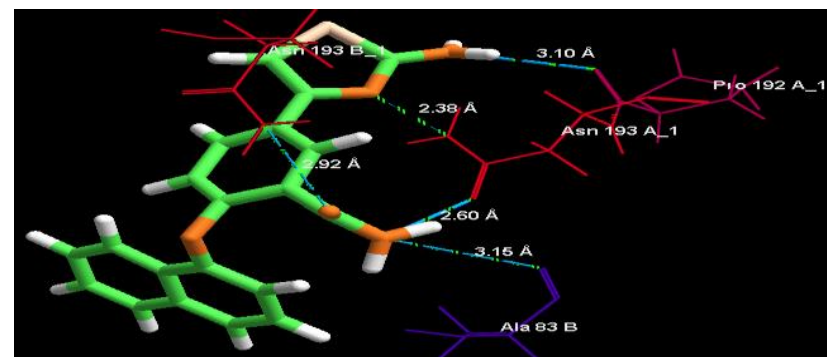

Figure 5(d) Compound $S_{7}$ showed interaction with bond lengths of amino-acids Pro192(3.10 $\AA$ ), $\operatorname{Asn193(2.38~\AA ⿱亠䒑)}), \operatorname{Asn193(2.60~\AA ̊),~} \operatorname{Ala83(3.15~\AA ̊̊)~}$ and $\operatorname{Asn193}(2.92 \AA)$

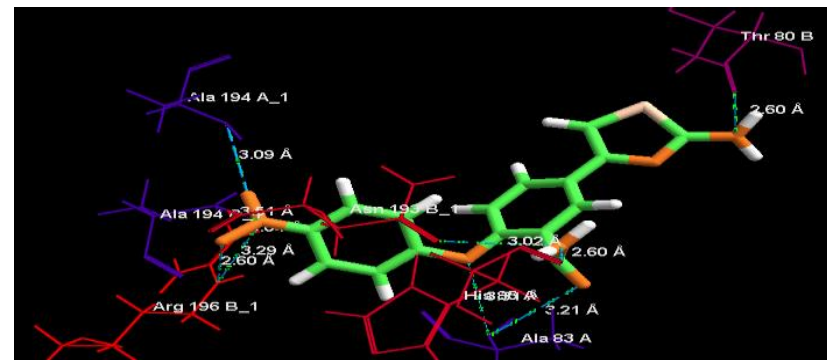

Figure 5 (f) Compound $S_{9}$ showed interaction with

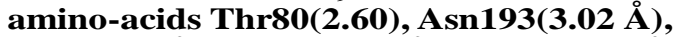
$\operatorname{His85}(2.60 \AA), \operatorname{Ala83(3.21} \AA), \operatorname{Ala83}(3.21 \AA)$,

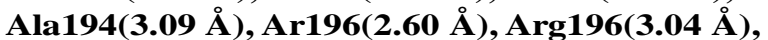
$\operatorname{Arg196}(3.29 \AA)$ and Ala194(3.51 $\AA$ ).

Figure 5 Interactions of different N-substituted thiazole derivatives with different amino acids of PDB ID 3iL9

\subsection{Biological Activity Predicted by PASS Online Software}

Biological activities of the above-discussed thiazole derivates were obtained through the database internet site. Using the PASS database for prediction of biological activity is an analysis on the base of known compounds and reference compounds with different biological activities. The result is predicted based on the Pa value. Here we have shown (Pa) and $(\mathrm{Pi}$ ) compounds in Table 3. While Pa>0.7, our compounds may be similar to known active pharmaceutical compounds. Based on this input, we can assume biological activities to be mucosal protective agents, serotonin release inhibitors, transcription factor STAT inhibitor, all of the synthesized compounds also show antibacterial and fungal activities, when $\mathrm{Pa}>0.5$ then the probability of similarity of the newly synthesized compound is less than reference drug [29].

By using PASS ONLINE software different biological potentials of the 2-4 disubstituted compounds $\left(\mathrm{S}_{1}\right.$ to $\left.\mathrm{S}_{10}\right)$ are describes as below in Table $\mathbf{3}$.

PASS $=$ (Prediction of Activity Spectra for Substances $)$ 
$\mathbf{P a}=($ Probability "to be active")

$\mathbf{P i}=($ Probability "to be inactive")

Table 3 Shows pass online software probable activities of synthesized compounds

\begin{tabular}{|c|c|c|c|}
\hline \multirow[t]{2}{*}{ Compounds } & \multicolumn{3}{|c|}{ Different Biological activity } \\
\hline & $\mathrm{Pa}$ & $\mathrm{Pi}$ & Activity \\
\hline \multirow{5}{*}{ Standard drug } & 0.803 & 0.003 & Phosphatase inhibitor \\
\hline & 0.729 & 0.034 & Chlordecone reductase inhibitor \\
\hline & 0.389 & 0.178 & Mucomembranous protector \\
\hline & 0.342 & 0.045 & Antibacterial \\
\hline & 0.238 & 0.113 & Antifungal \\
\hline \multirow{5}{*}{$\mathrm{S} 1$} & 0.855 & 0.008 & Mucoprotective \\
\hline & 0.726 & 0.004 & 5-HT release inhibitor \\
\hline & 0.476 & 0.005 & Anti-Helicobacter pylori \\
\hline & 0.401 & 0.109 & Antiviral (Picorna virus) \\
\hline & 0.334 & 0.048 & Antibacterial \\
\hline \multirow{5}{*}{$\mathrm{S} 2$} & 0.817 & 0.014 & Mucoprotective \\
\hline & 0.767 & 0.004 & 5-HT release inhibitor \\
\hline & 0.624 & 0.005 & Transcription factor STAT inhibitor \\
\hline & 0.375 & 0.036 & Antibacterial \\
\hline & 0.291 & 0.084 & Antifungal \\
\hline \multirow{5}{*}{ S3 } & 0.799 & 0.008 & Muramoyltetrapeptide carboxypeptidase inhibitor \\
\hline & 0.799 & 0.025 & Mucomembranous protector \\
\hline & 0.551 & 0.018 & 5-HT release inhibitor \\
\hline & 0.363 & 0.040 & Antibacterial \\
\hline & 0.216 & 0.127 & Antifungal \\
\hline \multirow{5}{*}{ S4 } & 0.762 & 0.010 & Muramoyltetrapeptide carboxypeptidase inhibitor \\
\hline & 0.587 & 0.016 & Insulin promoter \\
\hline & 0.336 & 0.058 & Antibacterial \\
\hline & 0.266 & 0.098 & Antifungal \\
\hline & 0.218 & 0.098 & Antineoplastic (bone cancer) \\
\hline \multirow{5}{*}{ S5 } & 0.857 & 0.003 & 5-HT release inhibitor \\
\hline & 0.596 & 0.011 & Histamine release inhibitor \\
\hline & 0.436 & 0.047 & Insulin promoter \\
\hline & 0.411 & 0.027 & Antibacterial \\
\hline & 0.334 & 0.068 & Antifungal \\
\hline
\end{tabular}


World Journal of Advanced Research and Reviews, 2020, 08(02), 043-055

\begin{tabular}{|c|c|c|c|}
\hline \multirow{5}{*}{ S6 } & 0.790 & 0.005 & Autoimmune disorders treatment \\
\hline & 0.788 & 0.004 & Rheumatoid arthritis treatment \\
\hline & 0.389 & 0.033 & Antibacterial \\
\hline & 0.308 & 0.092 & Antiulcerative \\
\hline & 0.224 & 0.068 & Antileukemic \\
\hline \multirow{5}{*}{ S7 } & 0.798 & 0.019 & Mucoprotective \\
\hline & 0.532 & 0.015 & STAT Transcription factor inhibitor \\
\hline & 0.499 & 0.005 & Anti-Helicobacter pylori \\
\hline & 0.331 & 0.049 & Antibacterial \\
\hline & 0.319 & 0.144 & Anti-inflammatory \\
\hline \multirow{5}{*}{ S8 } & 0.810 & 0.016 & Mucoprotective \\
\hline & 0.585 & 0.013 & 5-HT release inhibitor \\
\hline & 0.361 & 0.040 & Antibacterial \\
\hline & 0.303 & 0.012 & Gastric antisecretory \\
\hline & 0.307 & 0.084 & Antineoplastic (solid tumors) \\
\hline \multirow{5}{*}{ S9 } & 0.810 & 0.016 & Mucomembranous protector \\
\hline & 0.519 & 0.020 & Antiulcerative \\
\hline & 0.508 & 0.028 & Insulin promoter \\
\hline & 0.361 & 0.040 & Antibacterial \\
\hline & 0.277 & 0.092 & Antifungal \\
\hline \multirow{5}{*}{ S10 } & 0.857 & 0.008 & Mucomembranous protector \\
\hline & 0.819 & 0.007 & Muramoyltetrapeptide carboxypeptidase inhibitor \\
\hline & 0.560 & 0.007 & Immunomodulator \\
\hline & 0.310 & 0.057 & Antibacterial \\
\hline & 0.301 & 0.080 & Antifungal \\
\hline
\end{tabular}

\section{Conclusion}

The present research is designed to affirm the potent antifungal activity of ten novel 5-(2-aminothiazol-4-yl)-benzamide ethers $\left(\mathbf{S}_{\mathbf{1}}-\mathbf{S}_{\mathbf{1 0}}\right)$ (N-substituted thiazole derivatives). Thiazole moiety can target different receptors such as DNA gyrase, GlcN-6-P synthase, COX, LOX, DFHR, and MOA, etc, but 3iL9 was utilized as FabH inhibitor target PDB in the in silico studies to investigate the potent antifungal derivatives. Using Molegro software, compound $\mathrm{S}_{2}, \mathrm{~S}_{5}, \mathrm{~S}_{6}, \mathrm{~S}_{7}, \mathrm{~S}_{8}$, and $\mathrm{S}_{9}$ showed good antifungal activity but among all these, $\mathbf{S}_{\mathbf{9}}$ showed the most potent activity based on the doc score and hydrogen bond interaction as compared to the reference drug (Griseofulvin). Similarly in another in silico pharmacological study using online PASS software, compounds $S_{1}, S_{2}, S_{5}, S_{6}, S_{7}, S_{8}$, and $S_{9}$ showed potent antibacterial activity when compared with the standard drugs. Based on the above work, it can be concluded that thiazoles hold great importance particularly as antibacterial and antifungal agents when studied in silico. Thus the future research on the synthesize, in vitro, and in vivo antibacterial and antifungal assays of these 2-phenyl-amino thiazole derivatives can lead to the drug discovery of certain new FabH inhibiting agents as potent antimicrobial drugs 


\section{Compliance with ethical standards}

\section{Acknowledgments}

We express our sincere thanks to the Director of the Institute of Pharmaceutical Sciences, Kurukshetra University, Kurukshetra for providing necessary research facilities.

\section{Disclosure of conflict of interest}

The authors declare no conflict of interest.

\section{References}

[1] Kim SK, Kim JH, Park YC, Kim JW, Yum EK. Synthesis of trisubstituted thiazoles by ligand-free palladium-catalyzed direct 5-arylation of 2, 4-disubstituted thiazoles under conventional and microwave-assisted heating. Tetrahedron. 2013 Dec 23; 69(51):10990-5.

[2] Konstantinova LS, Bol'shakov OI, Obruchnikova NV, Laborie H, Tanga A, Sopéna V, Lanneluc I, Picot L, Sablé S, Thiéry V, Rakitin OA. One-pot synthesis of 5-phenylimino, 5-thieno or 5-oxo-1, 2, 3-dithiazoles and evaluation of their antimicrobial and antitumor activity. Bioorganic \& medicinal chemistry letters. 2009 Jan 1; $19(1): 136$-41.

[3] Yenilmez HY, Sevim AM, Bayır ZA. Synthesis and photophysics of new metallo phthalocyanine complexes with thiazole groups and their fluorescence quenching studies with benzoquinone. Synthetic metals. 2013 Jul 15; 176:11-7.

[4] Bikobo DS, Vodnar DC, Stana A, Tiperciuc B, Nastasă C, Douchet M, Oniga O. Synthesis of 2-phenylamino-thiazole derivatives as antimicrobial agents. Journal of Saudi Chemical Society. 2017 Nov 1; 21(7):861-8.

[5] Ansari M, Shokrzadeh M, Karima S, Rajaei S, Fallah M, Ghassemi-Barghi N, Ghasemian M, Emami S. New thiazole2 (3H)-thiones containing 4-(3, 4, 5-trimethoxyphenyl) moiety as anticancer agents. European journal of medicinal chemistry. 2020 Jan 1; 185:111784.

[6] Da Silva MG, Cardoso JF, Perasoli FB, Branquinho RT, Mourão RS, Tavares HD, Xocaira Ml, Guimarães DS, Viana GH, Varotti FD, Da Silva GR. Nanoemulsion composed of 10-(4, 5-dihydrothiazol-2-yl) thio) decan-1-ol), a synthetic analog of 3-alkylpiridine marine alkaloid: development, characterization, and antimalarial activity. European journal of pharmaceutical sciences. 2020 May 26:105382.

[7] Guan ZR, Liu ZM, Wan Q, Ding MW. One-pot four-component synthesis of polysubstituted thiazoles via cascade Ugi/Wittig cyclization starting from odorless Isocyano (triphenylphosphoranylidene)-acetates. Tetrahedron. 2020 Mar 6:131101.

[8] Jacob PJ, Manju SL. Identification and development of thiazole leads as COX-2/5-LOX inhibitors through in-vitro and in-vivo biological evaluation for anti-inflammatory activity. Bioorganic Chemistry. 2020 Apr 25:103882.

[9] Siddiqui AA, Partap S, Khisal S, Yar MS, Mishra R. Synthesis, Anti-Convulsant Activity and Molecular Docking Study of Novel Thiazole Pyridazinone Hybrid Analogues. Bioorganic Chemistry. 2020 Jan 27:103584.

[10] Kaddouri Y, Abrigach F, Yousfi EB, El Kodadi M, Touzani R. New thiazole, pyridine and pyrazole derivatives as antioxidant candidates: synthesis, DFT calculations and molecular docking study. Heliyon. 2020 Jan 1; 6(1):e03185.

[11] Rohs, R.; Bloch I, Sklenar H, Shakked Z, Molecular flexibility in ab-initio drug docking to DNA: binding-site and binding-mode transitions in all-atom Monte Carlo simulations. Nucl Acids Res.2005; 33:7048-7057.

[12] Guedes I.A, de Magalhães C.S, Dardenne L.E., Receptor-ligand molecular docking. Biophysical Reviews, 2014; 6:75-87.

[13] Agarwal S, Chadha D, Mehrotra R, Molecular modeling and spectroscopic studies of semustine binding with DNA and its comparison with lomustine-DNA adduct formation. J Biomol Struct Dyn, 2015; 33:1653-1668.

[14] Seeliger D, de Groot B.L,Ligand docking and binding site analysis with PyMOL and Autodock/Vina. J Comput Aided Mol Des, 2010; 24:417-422. 
[15] Dar AM, Mir S. Molecular docking: approaches, types, applications and basic challenges. J. Anal. Bioanal. Tech.,(2017); 8(2):1-7

[16] Shoichet BK, McGovern SL, Wei B, Irwin JJ, Lead discovery using molecular docking. Curr Opin Chem Biol, 2002; 6:439-446.

[17] Rock CO, Cronan JE. Escherichia coli as a model for the regulation of dissociable (type II) fatty acid biosynthesis. Biochimica et Biophysica Acta (BBA)-Lipids and Lipid Metabolism. 1996 Jul 12; 1302(1):1-6.

[18] Ohlrogge JB. Fatty acid synthetase: plants and bacteria have similar organization. Trends in biochemical sciences. 1982.

[19] Banerjee A, Dubnau E, Quemard A, Balasubramanian V, Um KS, Wilson T, Collins D, De Lisle G, Jacobs WR. inhA, a gene encoding a target for isoniazid and ethionamide in Mycobacterium tuberculosis. Science. 1994 Jan 14; 263(5144):227-30.

[20] McMurry, L.M; Oethinger M, Levy SB. Triclosan targets lipid synthesis. Nature. 1998 Aug; 394(6693):531-2.

[21] Heath RJ, Yu YT, Shapiro MA, Olson E, Rock CO. Broad spectrum antimicrobial biocides target the FabI component of fatty acid synthesis. Journal of Biological Chemistry. 1998 Nov 13; 273(46):30316-20.

[22] Waller RF, Keeling PJ, Donald RG, Striepen B, Handman E, Lang-Unnasch N, Cowman AF, Besra GS, Roos DS, McFadden GI. Nuclear-encoded proteins target to the plastid in Toxoplasma gondii and Plasmodium falciparum. Proceedings of the National Academy of Sciences. 1998 Oct 13; 95(21):12352-7.

[23] Jackowski S, Murphy CM, Cronan JE, Rock CO. Acetoacetyl-acyl carrier protein synthase. A target for the antibiotic thiolactomycin. Journal of Biological Chemistry. 1989 May 5; 264(13):7624-9.

[24] Tsay JT, Rock CO, Jackowski S. Overproduction of beta-ketoacyl-acyl carrier protein synthase I imparts thiolactomycin resistance to Escherichia coli K-12. Journal of Bacteriology. 1992 Jan 1; 174(2):508-13.

[25] Davies C, Heath RJ, White SW, Rock CO. The 1.8 Å crystal structure and active-site architecture of $\beta$-ketoacyl-acyl carrier protein synthase III (FabH) from Escherichia coli. Structure. 2000 Feb 1; 8(2):185-95.

[26] Aoki Y, Yoshihara F, Kondoh M, Nakamura Y, Nakayama N, Arisawa M. Ro 09-1470 is a selective inhibitor of P450 lanosterol C-14 demethylase of fungi. Antimicrob. Agents Chemother. 1993; 37:2662-2667.

[27] El-Achkar GA, Jouni M, Mrad MF, Hirz T, El Hachem N, Khalaf A, Hammoud S, Fayyad-Kazan H, Eid AA, Badran B, Merhi RA. Thiazole derivatives as inhibitors of cyclooxygenases in-vitro and in-vivo. European journal of pharmacology. 2015 Mar 5; 750:66-73.

[28] Khodairy A, Moustafab AH, Ahmed WW. Hetarylcyanamides: Synthesis of novel thiazole, triazole and pyrimidine derivatives and prediction of their biological activity via PAA Inet. Journal of pharmaceutical and applied chemistry an international journal. 2017 Sep. 1; (3):267-73. 